\title{
A fractured arm and forgotten contraceptive implant
}

\author{
Annette Thwaites, $^{1,2}$ Yathish Shenava ${ }^{3}$
}

${ }^{1}$ EGA Institute for Women's Health, UCL, London, UK ${ }^{2}$ Sexual and Reproductive Health, King's College Hospital NHS Foundation Trust, London, UK

${ }^{3}$ Trauma and Orthopaedic Surgery, Queen Elizabeth Hospital, London, UK

\section{Correspondence to} Dr Annette Thwaites, annettethwaites@doctors. org.uk

Accepted 29 May 2019

\section{DESCRIPTION}

The progestogen-only contraceptive implant is a single, non-biodegradable, flexible rod licensed for up to three years of use. ${ }^{12}$ It is the most effective contraceptive method currently available ${ }^{3}$ and the most common type of long-acting reversible contraception prescribed in NHS sexual and reproductive (SRH) services. ${ }^{4}$ Its popularity has risen steadily over the last 10 years and it is now the main method of contraception for $16 \%$ of females seen in these services. ${ }^{4}$

When inserted correctly the implant should be situated subdermally and significant migration is not then thought to occur. ${ }^{15}$ The SPC for Nexplanon states that there have been 'occasional reports of migration of the implant; usually this involves minor movement relative to the original position, but may lead to the implant not being palpable at the location in which it was placed'. ${ }^{2}$

A literature search of the PubMed database (2000-2018) found rare cases of etonogestrel implant migration into the vasculature ${ }^{67}$ but no

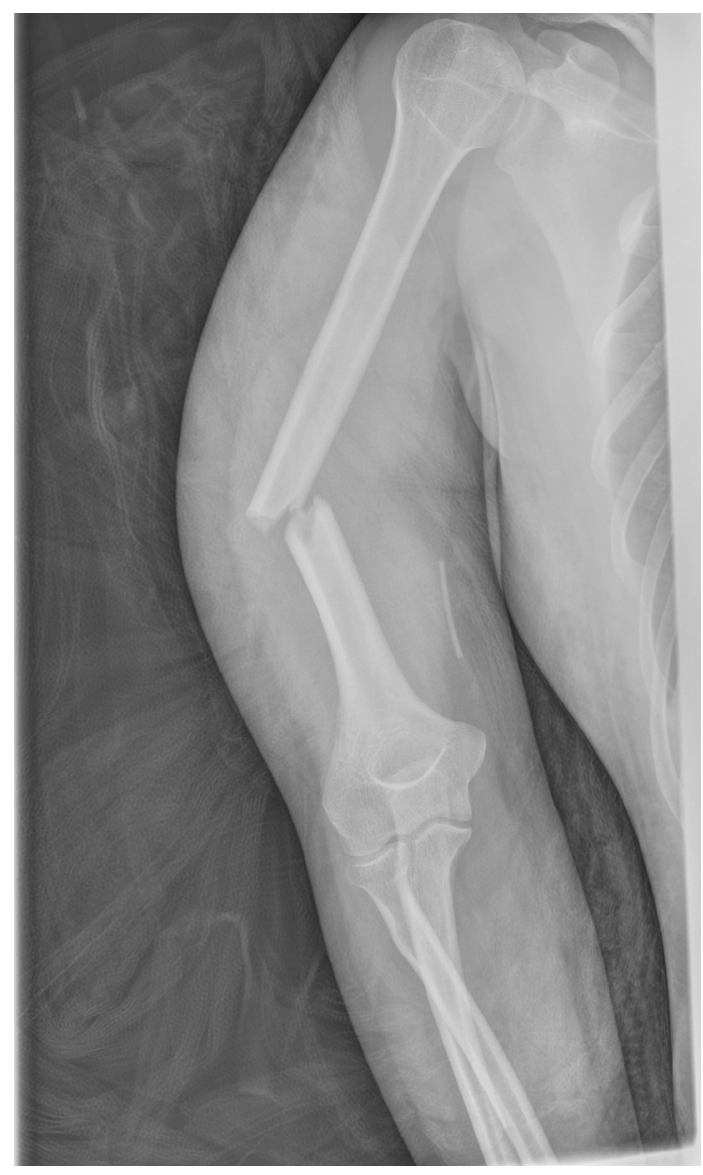

Figure 1 AP radiograph shows the displaced transverse fracture and Nexplanon contraceptive implant. evidence of migration subsequent to arm fractures or trauma. This case suggests the possibility of migration secondary to significant trauma, fracture and/or subsequent muscle atrophy.

A 26-year-old woman presented to the emergency department with pain and deformity of the right arm having suffered a fall down icy, concrete steps in December 2017. She had an expired, Nexplanon implant in situ in her right upper arm. The implant was not mentioned by the patient at initial presentation nor at any point during her orthopaedic care. Her medications were noted as microgynon, oral contraceptive pill, only. She had been taking this for the last year since the expiry of her implant. The presence of her implant was not documented in her clinical notes nor multiple radiology reports.

An anteroposterior (AP) radiograph shows a closed, displaced, mid-shaft, transverse, right humeral fracture and the expired Nexplanon contraceptive implant (figure 1).

The woman was treated conservatively with a Clasby brace for a period of two months immobilisation. She was discharged from fracture clinic three months after her injury, pain-free but with limited range of movement (forward flexion to $140^{\circ}$, abduction to $140^{\circ}$ and internal rotation to L3) and planned physiotherapy follow-up.

Four months after her accident, the woman presented to a walk-in community SRH clinic requesting removal of her implant. The implant was impalpable. The patient reported being able to palpate the device easily after its insertion

\section{Patient's perspective}

When I fractured my arm, and over the several months of recovery, I did not give my implant a second thought aside from knowing I needed to get it taken out when I was out of my cast. Looking back at the X-rays I took photos of during fracture clinic, it can be seen quite clearly and I am surprised that over several appointments no one asked what it was!

The process of getting it taken out was painless, but I was concerned to find it had moved and it was difficult to find. Luckily I had photos of my $\mathrm{X}$-rays on my phone to use as guidance, but I only had these as I had requested to take photos at my fracture clinic appointment.

I had an implant prior to this one and the procedure was so simple so it did not occur to me that it would move round during my recovery. Fortunately, I was not relying on this for birth control and was using a different method at this point. 


\section{Learning points}

- Contraceptive implants are increasingly common and encountered in a variety of healthcare settings. Increased awareness of contraceptive implants, across specialities (eg, emergency department, orthopaedics and radiology) is necessary as these may have implications for management (eg, drug interactions or upper arm surgery) and provide an opportunity for early identification of impalpable implants or other complications.

- Patients do not always remember or recognise the relevance of their implant, particularly if it has expired or in the context of trauma. Healthcare professionals should be aware of the possibility of contraceptive implants in women of reproductive age presenting with upper limb conditions and ask directly about them.

- Patients should be referred to specialist sexual and reproductive health (SRH) services for removal of impalpable implants under ultrasound guidance. Local pathways differ and this is best carried out via GPs. Patients should be advised to use additional contraception until an impalpable implant has been confirmed to be in situ, intact and in date.

approximately fouryears previously by her general practitioner (GP) and, on direct questioning, said she had not been able to feel it since her fracture and associated muscle wastage. She felt that this may have caused it to move deeper.

The patient was referred for removal under ultrasound guidance with a high-frequency linear array transducer at an expert implant removal centre, as per current guidance. ${ }^{12}$ Although the positioning was challenging, as the patient's arm was unable to lie flat when externally rotated, the deep implant removal was carried out successfully without complication using the u-technique and modified ringed vasectomy forceps.

Acknowledgements The authors would like to thank the patient for her support of and contribution to this article.

Contributors AT saw the patient in specialist SRH clinic and removed her implant and YS was responsible for the patient's orthopaedic care and follow up. Both authors worked together to source and compile the patient's images, reports and notes across these services and AT drafted the case report with YS input.

Funding The authors have not declared a specific grant for this research from any funding agency in the public, commercial or not-for-profit sectors.

Competing interests None declared.

Patient consent for publication Obtained.

Provenance and peer review Not commissioned; externally peer reviewed.

\section{REFERENCES}

1 Faculty of Sexual \& Reproductive Healthcare. Progestogen-only Implants. 2014. Available: https://www.fsrh.org/standards-and-guidance/documents/cec-ceu-guidanceimplants-feb-2014/

2 Nexplanon (etonogestrel) Summary of Product Characteristics. 2016. Available: http:// emc.medicines.org.uk/

3 Trussell J. Contraceptive efficacy. In: Hatcher R, Trussell J, Nelson AL, Cates W, Kowal D, Policar M, et al. eds. Contraceptive Technology. 20th Revised edn. New York, NY: Ardent Media, 2011:779-863

4 Statistics on Sexual and Reproductive Health Services (Contraception) England, 2017;18. Available: https://digital.nhs.uk/data-and-information/publications/statistical/ sexual-and-reproductive-health-services/2017-18

5 Migration of Implanon. Ismail, Mansour \& Singh. 2006. Available: https://srh.bmj.com/ content/32/3/157.long

6 Faculty of Sexual and Reproductive Healthcare. Intravascular insertion of Nexplanon. Available: http://www.fsrh.org/standards-and-guidance/documents/ceu-statementintravascular-insertion-of-nexplanon-june-2016/

7 Rowlands S, Mansour D, Walling M. Intravascular migration of contraceptive implants: two more cases. Contraception 2017:95:211-4.

Copyright 2019 BMJ Publishing Group. All rights reserved. For permission to reuse any of this content visit

https://www.bmj.com/company/products-services/rights-and-licensing/permissions/

BMJ Case Report Fellows may re-use this article for personal use and teaching without any further permission.

Become a Fellow of BMJ Case Reports today and you can:

- Submit as many cases as you like

- Enjoy fast sympathetic peer review and rapid publication of accepted articles

- Access all the published articles

Re-use any of the published material for personal use and teaching without further permission

Customer Service

If you have any further queries about your subscription, please contact our customer services team on +44 (0) 2071111105 or via email at support@bmj.com.

Visit casereports.bmj.com for more articles like this and to become a Fellow 